\title{
Herbicides cross resistance of a multiple resistant short-awn foxtail (Alopecurus aequalis Sobol.) population in wheat field
}

Wenlei Guo ${ }^{1}$, Lingling $\mathrm{Lv}^{1}$, Lele Zhang ${ }^{1}, \mathrm{Qi} \mathrm{Li}^{1}$, Cuixia $\mathrm{Wu}^{2}$, Xingtao Lu², Weitang Liu ${ }^{1}$, and Jinxin Wang ${ }^{1 *}$

\section{ABSTRACT}

Alopecurus aequalis Sobol. is a common grass weed, which has become increasingly troublesome to control in China wheat fields. One A. aequalis population, collected from Anhui Province China, was suspected to be resistant to fenoxaprop- $P$-ethyl and mesosulfuron-methyl. This study aimed to establish the cross-resistance pattern using the purified subpopulation and explore the potential targetsite and non-target-site based resistance mechanisms. Sequencing results showed that a single nucleotide change of ATT to AAT was present in acetyl-CoA carboxylase (ACCase) gene of the resistant $(\mathrm{R})$ plants, resulting in an $\mathrm{Ile}_{2041}$ Asn amino acid substitution. Besides, another single nucleotide change of CCC to CGC was present in acetolactate synthase (ALS) gene of the R plants, resulting in a Pro ${ }_{197}$ Arg amino acid substitution. The homozygous resistant plants were isolated and the seeds were used in whole-plant herbicide bioassays. Compared with the susceptible (S) population, R population displayed high level resistance to fenoxaprop- $P$-ethyl and mesosulfuronmethyl. Cross resistance patterns showed that the $\mathrm{R}$ population was highly resistant to clodinafop-propargyl, moderately resistant to pyroxsulam and flucarbazoncsodium, lowly resistant to pinoxaden, and susceptible to tralkoxydim, sethoxydim, and isoproturon. The pretreatment of piperonyl butoxide reduced the $50 \%$ growth reduction $\left(\mathrm{GR}_{50}\right)$ value of fenoxaprop- $P$-ethyl, suggesting that target-site resistance and non-target-site resistance mechanisms were both present in fenoxaprop$P$-ethyl-resistance of $A$. aequalis. This is the first report of ACCase $\mathrm{Ile}_{2041}$ Asn and ALS Pro ${ }_{197}$ Arg mutation in $A$. aequalis.

Key words: Acetolactate synthase, acetyl-CoA carboxylase, cytochrome $\mathrm{P} 450$, mutation, resistance.

${ }^{1}$ Shandong Agricultural University, College of Plant Protection, Taian, 271018, China. "Corresponding author (wangjx@sdau.edu.cn).

${ }^{2}$ Taian Academy of Agricultural Sciences of Shandong Province, Taian, 271000, China.

Received: 10 December 2015.

Accepted: 22 March 2016.

doi:10.4067/S0718-58392016000200005

\section{INTRODUCTION}

Short-awn foxtail (Alopecurus aequalis Sobol.) is a winter-annual grass weed infesting wheat (Triticum aestivum L.) production in some regions of China, especially in the lower-middle reaches of the Yangtze River (Zhang, 2003). Alopecurus aequalis has a strong reproductive capacity and the seeds easily flutter to the ground, which guarantees its competitiveness against wheat seedlings. It was reported that wheat yield reduced $24.2 \%$ and $51.9 \%$ infested with $A$. aequalis at 540 to 675 and 1197 to 1560 plants $\mathrm{m}^{-2}$, respectively (Zhu and Tu, 1997).

Fenoxaprop- $P$-ethyl belongs to the aryloxyphenoxypropionate (APP) herbicide class and it can inhibit the activity of acetylCoA carboxylase (ACCase; EC 6.4.1.2), which is a key enzyme that catalyzes the first step of fatty acid biosynthesis. In plants, two different ACCase forms are identified in the chloroplast and in the cytosol respectively (Konishi et al., 1996). In most plant species, the cytosolic ACCase is a multidomain enzyme and the chloroplastic ACCase is a multisubunit enzyme (Incledon and Hall, 1997). However, both cytosolic and chloroplastic ACCase are multidomain in the Poaceae (grasses) family (Sasaki and Nagano, 2004). Interestingly, the multisubunit ACCase and multidomain ACCase in the cytosol are insensitive to herbicides (Konishi and Sasaki, 1994). On the contrary, the multidomain chloroplastic ACCase in grass species is sensitive to three distinct classes of herbicides, namely the APPs, the cyclohexanediones (CHDs) and the phenylpyrazoline herbicide pinoxaden (DEN) (Herbert et al., 1997; Hofer et al., 2006). Previous studies have proved that the carboxyl transferase (CT) domain of the multidomain chloroplastic ACCase is the target for ACCase-inhibiting herbicides (Zhang et al., 2003). In China, postemergence application of fenoxaprop- $P$ ethyl has been extensively used to control A. aequalis and other grass weeds in wheat fields since 1990s. Moreover, in some areas, people applied it as the unique method for grass weed control. As a result, the control effect on grass weeds declined gradually by fenoxaprop- $P$-ethyl and at least eight weed species, including $A$. aequalis, have evolved resistance to fenoxaprop- $P$-ethyl and/or other ACCase inhibitors in China (Heap, 2015).

Mesosulfuron-methyl is a sulfonylurea (SU) compound that targets the biosynthetic pathway of branched chain amino acids by inhibiting the activity of enzyme acetolactate synthase (ALS, EC 4.1.3.18). Besides the SUs, ALS-inhibiting herbicides also include four more dissimilar chemical classes: imidazolinones (IMIs), triazolopyrimidines (TPs), pyrimidinylthiobenzoates (PTBs), and sulfonylaminocarbonyltriazolinones (SCTs) (Duggleby et 
al., 2008). As an ALS-inhibiting herbicide, mesosulfuronmethyl has a high herbicidal activity towards a wide spectrum of grass weeds and several broad-leaved weeds. Since its registration in China in 2004, mesosulfuron-methyl has become a popular product for grass weeds management in wheat fields, especially for the control of ACCase resistant weed species. Similar to the resistance to ACCase herbicides, however, weed resistance to herbicides with this action site can be selected with fewer than ten treatments (Beckie, 2006). In recent years, mesosulfuron-methyl resistance is beginning to emerge in some regions of China.

Target-site resistance (TSR) and non-target-site resistance (NTSR) are the main mechanisms resulting in herbicide resistance (Powles and Yu, 2010). Generally, TSR is mainly caused by single amino acid substitution in the target enzyme prohibiting herbicides from effective binding. Up to now, 13 amino acid substitutions, locating at seven points in the $\mathrm{CT}$ domain of ACCase, have been proved to result in ACCase herbicides resistance (Powles and Yu, 2010; Kaundun, 2014): Ile ${ }_{1781} \mathrm{Leu} / \mathrm{Val} / \mathrm{Thr}$, Trp ${ }_{1999} \mathrm{Cys} / \mathrm{Leu} /$ Ser, Trp 2027 Cys, $\mathrm{Ile}_{2041} \mathrm{Asn} / \mathrm{Val}, \mathrm{Asp}_{2078} \mathrm{Gly}, \mathrm{Cys}_{2088} \mathrm{Arg}$, and Gly ${ }_{2096} \mathrm{Ala} / \mathrm{Ser}$ (amino acid residue numbering is according to the A. myosuroides ACCase sequence, GenBank accession AJ310767). Similarly, 26 target-site substitutions that make the enzyme be insensitive to ALS-inhibiting herbicides have been found in eight positions of ALS gene (Powles and Yu, 2010; Beckie and Tardif, 2012; Tranel et al., 2015): $\operatorname{Ala}_{122}$ (3), Pro $_{197}$ (12), $\operatorname{Ala}_{205}$ (1), $\operatorname{Asp}_{376}$ (1), $\operatorname{Arg}_{377}$ (1), Trp 574 (3), Ser 653 (3), and $\mathrm{Gly}_{654}$ (2) (bracketed number represents the amount of substitutions at specific position; amino acid residue numbering is according to the Arabidopsis thaliana ALS sequence, GenBank accession NM_114714.2). Target-site based mechanism, such as ACCase and ALS gene mutations listed above, usually confers cross resistance to herbicides with the same action site. Nonetheless, different substitutions or the same substitution in different weed species may confer various cross resistance patterns (Yu and Powles, 2014a).

Non-target-site resistance to ACCase- and ALS-inhibiting herbicides is now recognized to be widespread in several weed species, including A. myosuroides (Délye et al., 2010), Bromus rigidus (Owen et al., 2012), and Lolium rigidum (Han et al., 2016). Metabolic resistance is a leading member in NTSR, and it can enhance metabolic capacity of the plant to detoxify herbicides, which reduces the amount of active ingredient of herbicide reaching target site. Unlike TSR, metabolic resistance usually confers an unpredictable crossresistance pattern (Yu and Powles, 2014b). Nevertheless, whether or not cytochrome $\mathrm{P} 450$ monooxygenase plays a role in multiple resistance of $A$. aequalis to fenoxaprop- $P$ ethyl and mesosulfuron-methyl is still a mystery.

In this article, we aimed to (1) identify target-site mutation(s) in ACCase and ALS gene respectively; (2) conduct preliminary studies on the role of cytochrome P450 monooxygenase in multiple herbicide-resistant $A$. aequalis; and (3) evaluate the cross-resistance patterns to other herbicides using the purified homozygous resistant population.

\section{MATERIALS AND METHODS}

\section{Plant material, herbicides, and chemicals}

Seeds of the putative resistant (R) Alopecurus aequalis population were collected from a wheat field in Shou county, Anhui province (32॰05'11.4” N; 116 53'28.8” E), China, where fenoxaprop- $P$-ethyl, clodinafop-propargyl and mesosulfuron-methyl had been continuously used for many years. A susceptible (S) population collected from an uncultivated land in Rizhao, Shandong province ( $35^{\circ} 16^{\prime}$ '5.7' $\mathrm{N} ; 119^{\circ} 22^{\prime} 7.7^{\prime \prime} \mathrm{E}$ ), was used as the control in this study. Seed samples were air-dried and stored in sealed paper bags at $4{ }^{\circ} \mathrm{C}$ until used.

The herbicides used in this study were ACCase inhibitors: fenoxaprop- $P$-ethyl (ethyl (R)-2-[4-(6-chloro1,3-benzoxazol-2-yloxy)phenoxy]propionate; $69 \mathrm{~g} \mathrm{~L}^{-1} \mathrm{EW}$, Bayer, Hangzhou, China); clodinafop-propargyl (prop-2ynyl $(R)$-2-[4-(5-chloro-3-fluoro-2-pyridyloxy)phenoxy] propionate; $15 \% \mathrm{WP}$, Syngenta); sethoxydim $((5 R S)$ 2-[(EZ)-1-(ethox yimino)butyl]-5-[(2RS)-2-(ethylthio) propyl]-3-hydroxycyclohex-2-en-1-one; $12.5 \%$ EC, Soda, Tianjin, China); tralkoxydim ((RS)-2-[(EZ)-1-(ethoxyimino) propyl]-3-hydroxy-5-mesitylcyclohex-2-en-1-one; $40 \%$ WDG, Jiangsu Agrochem Laboratory, Changzhou, China); pinoxaden (8-(2,6-diethyl-p-tolyl)-1,2,4,5-tetrahydro7-oxo-7 H-pyrazolo[ $1,2-d][1,4,5]$ oxadiazepin-9-yl 2,2-dimethylpropionate; $5 \%$ EC, Syngenta); ALS inhibitors: mesosulfuron-methyl (methyl 2-[(4,6-dimethoxypyrimidin2 -ylcarbamoyl)sulfamoyl]- $\alpha$-(methanesulfonamido)- $p$ toluate; $30 \mathrm{~g} \mathrm{~L}^{-1} \mathrm{OF}$, Bayer); flucarbazone-sodium (sodium [(4,5-dihydro-3-methoxy-4-methyl-5-oxo-1 $\mathrm{H}$-1,2,4-triazol1-yl)carbonyl]\{[2-(trifluoromethoxy)phenyl]sulfonyl\} azanide; 70\% WDG, Arysta LifeScience, Shanghai, China); pyroxsulam $\quad(N$-(5,7-dimethoxy[1,2,4]triazolo[1,5- $a]$ pyrimidin-2-yl)-2-methoxy-4-(trifluoromethyl)pyridine3-sulfonamide; 7.5\% WDG, Dow AgroSciences); and photosystem II inhibitor isoproturon (3-(4-isopropylphenyl)1,1-dimethylurea; 50\% WP, Bianjing, Suzhou, China). Piperonyl butoxide (PBO; 5-[2-(2-butoxyethoxy) ethoxymethyl]-6-propyl-1,3-benzodioxole, 97\%) was purchased from Aladdin (Shanghai, China).

\section{Acquisition of purified resistant population homozygous for ACCase and ALS mutations}

Prior to planting, seeds of the R population were pretreated and germinated as described in Guo et al. (2015). After germinated, 50 seeds were selected and separately transferred to 50 pots $(12-\mathrm{cm}$ diameter) with loam soils. The pots were placed in an artificial chamber and the culture conditions were the same as described in Guo et al. (2015). Three weeks after, fenoxaprop- $P$-ethyl at $62.1 \mathrm{~g}_{\text {ai ha }}{ }^{-1}$ and mesosulfuron-methyl at $9 \mathrm{~g}$ ai ha ${ }^{-1}$ were treated to 20 plants of the $\mathrm{R}$ population, respectively. The remaining 10 plants 
as control were treated with water. Each surviving plant was sampled for both ACCase and ALS gene sequencing. Sequencing results $(\mathrm{n}=48)$ showed that 16 plants were homozygous resistant both at ACCase 2041 and at ALS 197 codon position. These homozygous resistant plants were segregated and cultured in an artificial chamber to ensure no other pollen was introduced. When they were ripe, seeds from this purified resistant population were harvested and then used in herbicide dose-response experiments.

\section{ACCase and ALS gene sequencing}

Genomic DNA was extracted from young leaf material (about $80 \mathrm{mg}$, 2- to 3-leaf stage) of individual $\mathrm{R}$ and $\mathrm{S}$ plants by CTAB method. Two pairs of primers were used to amplify A. aequalis ACCase and ALS gene fragments containing all the known mutation sites in ACCase and AHAS gene, respectively. The detailed information of primers used in this study was showed in Table 1 . The polymerase chain reaction (PCR) system was the same as described in Guo et al. (2015), except that the total volume was $50 \mu \mathrm{L}$. PCR was conducted using T100 Thermal cycler (Bio-Rad, America), with the following reaction program: $94{ }^{\circ} \mathrm{C}$ for $5 \mathrm{~min}$, then 35 cycles of $94{ }^{\circ} \mathrm{C}$ for $30 \mathrm{~s}, \mathrm{X}{ }^{\circ} \mathrm{C}$ for $40 \mathrm{~s}$, and $72{ }^{\circ} \mathrm{C}$ for $40 \sim 120 \mathrm{~s}$, followed by a final step of $8 \mathrm{~min}$ at $72{ }^{\circ} \mathrm{C}$. The PCR products were purified using the EasyPure Quick Gel Extraction Kit (TransGen Biotech, Beijing, China) and sequenced using the corresponding primers (Table 1). The DNA fragment and translated amino acid sequences of ACCase and ALS gene were aligned and compared respectively.

\section{Cross resistance to herbicides}

Seeds from the $\mathrm{S}$ and the purified $\mathrm{R}$ populations were germinated, sowed and cultured as described in Guo et al. (2015). Before dose-response experiment, 20 plants (3- to 4- leaf stage) were treated with each herbicide at the single field rate (Table 2) to confirm herbicide susceptibilities of the $\mathrm{S}$ population. As expected, all plants from the $\mathrm{S}$ population were totally dead within $7 \mathrm{~d}$ under treatment of each herbicide.

When the seedlings grew to 3- to 4-leaf stage, herbicides were sprayed using a moving nozzle cabinet sprayer equipped with one 9503EVS flat fan nozzle (TeeJet Technologies, Wheaton, Illinois, USA) delivering $450 \mathrm{~L} \mathrm{ha}^{-1}$ at pressure of $280 \mathrm{kPa}$. The herbicide doses applied to the $\mathrm{R}$ and $\mathrm{S}$ populations were listed in Table 2 . Thirty minutes after application, all pots were returned to the greenhouse. Dry weight of the above-ground part of the plants was recorded at $21 \mathrm{~d}$ after treatment. The whole experiment was conducted twice and each treatment had three replicates.

\section{Fenoxaprop- $P$-ethyl dose response with and without PBO pretreatment}

Alopecurus aequalis seeds from the $\mathrm{S}$ and purified $\mathrm{R}$ populations were germinated and cultured as described above. Plants were treated with PBO, fenoxaprop- $P$-ethyl, and PBO plus fenoxaprop- $P$-ethyl at the 3 - to 4-leaf stage. PBO was applied two times, each with $2100 \mathrm{~g}$ ai ha ${ }^{-1}$ in $97 \mathrm{~L} \mathrm{ha}^{-1}$ water, to give a total rate of $4200 \mathrm{~g}^{\text {ai h ha }}{ }^{-1}$ in $194 \mathrm{~L}$ water ha-1

Table 1. Primers used in this study.

\begin{tabular}{|c|c|c|c|c|}
\hline Primers & Sequence $\left(5^{\prime}-3^{\prime}\right)$ & $\begin{array}{c}\text { Annealing } \\
\text { temperature }\left({ }^{\circ} \mathrm{C}\right)\end{array}$ & Usage & Reference \\
\hline AC-F1 & TTTCCCAGCGGCAGACAGAT & 55 & PCR and ACCase sequencing & Bi et al., 2016 \\
\hline AC-R1 & TCCCTGGAGTCTTGCTTTCA & & & \\
\hline AL-F1 & CGTCGCCTTACCCAAACCTAC & 59.6 & PCR and ALS sequencing & Guo et al., 2015 \\
\hline AL-R1 & RTCCTGCCATCACCWTCCA & & & \\
\hline AL-F2 & ATTGCCCGCCTTCCTAAGCC & & ALS sequencing & This article \\
\hline AL-F3 & TCATTGCCACTGGTGTTGGGC & & ALS sequencing & This article \\
\hline
\end{tabular}

PCR: Polymerase chain reaction; ACCase: acetyl-coenzyme A carboxylase; ALS: acetolactate synthase.

Table 2. Herbicide doses applied to the resistant (R) population and the susceptible (S) population of Alopecurus aequalis in doseresponse experiments. The recommended field rates are shown in bold.

\begin{tabular}{|c|c|c|}
\hline \multirow[b]{2}{*}{ Herbicide } & \multicolumn{2}{|c|}{ Application doses } \\
\hline & Resistant population (R) & Susceptible population (S) \\
\hline & - & \\
\hline \multicolumn{3}{|l|}{ ACCase inhibitors } \\
\hline Fenoxaprop- $P$-ethyl & $0,20.7, \mathbf{6 2 . 1}, 186.3,558.9,1676.7,5030.1$ & $0,0.8,2.3,6.9,20.7, \mathbf{6 2 . 1}, 186.3$ \\
\hline Fenoxaprop- $P$-ethyl $+\mathrm{PBO}$ & $0,20.7, \mathbf{6 2 . 1}, 186.3,558.9,1676.7,5030.1$ & $0,0.8,2.3,6.9,20.7, \mathbf{6 2 . 1}, 186.3$ \\
\hline Clodinafop-propargyl & $0,15, \mathbf{4 5}, 135,405,1215,3645$ & $0,0.6,1.7,5,15, \mathbf{4 5}, 135$ \\
\hline Tralkoxydim & $0,4.8,14.4,43.3,130, \mathbf{3 9 0}, 1170$ & $0,4.8,14.4,43.3,130, \mathbf{3 9 0}, 1170$ \\
\hline Sethoxydim & $0,1.9,5.6,16.7,50, \mathbf{1 5 0}, 450$ & $0,1.9,5.6,16.7,50, \mathbf{1 5 0}, 450$ \\
\hline Pinoxaden & $0,1.4,2.8,5.6,11.3,22.5, \mathbf{4 5}, 90$ & $0,0.7,1.4,2.8,5.6,11.2,22.5,45$ \\
\hline \multicolumn{3}{|l|}{ ALS inhibitors } \\
\hline Mesosulfuron-methyl & $0,3,9,27,81,243,729$ & $0,0.1,0.3,1,3,9,27$ \\
\hline Pyroxsulam & $0,0.13,0.4,1.2,3.5, \mathbf{1 0 . 6}, 31.7$ & $0,0.04,0.13,0.4,1.2,3.5, \mathbf{1 0 . 6}$ \\
\hline Flucarbazone-sodium & $0,0.5,2.0,7.9, \mathbf{3 1 . 5}, 126,504$ & $0,0.12,0.5,2.0,7.9, \mathbf{3 1 . 5}, 126$ \\
\hline \multicolumn{3}{|l|}{ Photosystem II inhibitor } \\
\hline Isoproturon & $0,28,56,112,225,450,900$ & $0,28,56,112,225,450,900$ \\
\hline
\end{tabular}

ACCase: Acetyl-coenzyme A carboxylase; PBO: piperonyl butoxide; ALS: acetolactate synthase. 
(Wang et al., 2013). PBO was formulated in a mixture of Tween-80 (1 mL L $\left.{ }^{-1}\right)$ and acetone and applied $1 \mathrm{~h}$ prior to herbicide application (Preston et al., 1996). Control plants were sprayed with aqueous solution of the emulsifier and hydrocarbon solvent mixture. The doses of fenoxaprop- $P$ ethyl were showed in Table 2, with or without PBO. Treated plants were harvested after $21 \mathrm{~d}$, when dry weights of the above-ground part were assessed.

\section{Data analyses}

The dry weight data were converted to a percentage of the control. Data were pooled because the two repeated experiments had nonsignificant difference in responses of the control. The herbicide doses causing 50\% growth reduction $\left(G_{50}\right)$ in the $R$ and $S$ populations were calculated by using a four-parameter log-logistic model (Seefeldt et al., 1995) (SigmaPlot 12.5 software; Systat Software, San Jose, California, USA):

$$
y=\mathrm{C}+(\mathrm{D}-\mathrm{C}) /\left\{1+\exp \left[\mathrm{b}\left(\log x-\log \mathrm{GR}_{50}\right)\right]\right\}
$$

where $C$ is the lower limit, $D$ is the upper limit and $b$ is the slope of the curve via the $\mathrm{GR}_{50}$ value. The resistance index (RI) was indicated by the ratio of $\mathrm{GR}_{50}$ between the $R$ and $S$ population.

\section{RESULTS}

\section{ACCase and ALS gene sequencing}

A 1437 bp PCR fragment of the A. aequalis ACCase gene covering the seven verified mutation sites was amplified from 48 individuals (20 survived fenoxaprop- $P$-ethyl treatment, 18 survived mesosulfuron-methyl treatment, and 10 control plants) of the $\mathrm{R}$ population, as well as from 10 individual plants of the $\mathrm{S}$ population. Comparison of the sequences between $\mathrm{R}$ and $\mathrm{S}$ samples revealed only an amino acid substitution: a single nucleotide change of ATT to AAT, resulting in an $\mathrm{Ile}_{2041}$ Asn substitution (Figure 1a). What's more, all the 48 individuals of the $\mathrm{R}$ population were homozygous for this ACCase mutation.

Figure 1. Alignment of partial amino acid sequences of plastid ACCase and ALS gene from resistant (R) and susceptible (S) Alopecurus aequalis populations. The boxed codons indicate: (a) I2041N mutation in ACCase gene of $\mathrm{R}$ population; (b) P197R mutation in ALS gene of $R$ population.

Alopecurus aequalis-R GFSGGQRDLFECN QAGSTI VEN

(a) Alopecurus aequalis-S GFSGGQRDLFEGI LQAGSTI VEN Alopecurus myosuroides GF SGGQRDLFEQI QAGSTI VEN

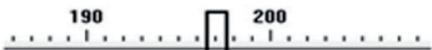

Alopecurus aequalis-R SI PNVAI TGQYRRRMI GTDAF QE

(b) Alopecurus aequalis-S SI PNVAI TGQYPRRMI GTDAFQE Arabidopsis thaliana SVPLVAI TGQVPRRM GTDAFQE

ACCase: Acetyl-coenzyme A carboxylase; ALS: acetolactate synthase.
Similarly, an 1859 bp PCR fragment of the ALS gene including the five highly conserved domains was amplified from the above 48 plants of the $\mathrm{R}$ population and 10 plants of the $\mathrm{S}$ population. Comparison of the sequence data showed a single nucleotide change of CCC to CGC, leading to a Pro ${ }_{197}$ Arg mutation in the R population (Figure 1b). Among the 48 plants sequenced, 16 plants were homozygous and 26 plants were heterozygous for the Pro ${ }_{197}$ Arg mutation. The remaining six plants did not have any documented ALS gene mutation. Accordingly, in total, 16 plants were homozygous both for ACCase $\mathrm{Ile}_{2041}$ Asn mutation and for ALS Pro ${ }_{197} \mathrm{Arg}$ mutation, and they were bulked to produce the purified $\mathrm{R}$ population.

To verify the purity of the population, 20 plants were randomly chosen and sequenced from the purified $\mathrm{R}$ and $\mathrm{S}$ population, respectively. As expected, all the purified $\mathrm{R}$ plants possessed homozygous $\mathrm{Ile}_{2041} \mathrm{Asn}$ and $\mathrm{Pro}_{197} \mathrm{Arg}$ mutations, and no documented mutation was detected in plants of the $\mathrm{S}$ population.

\section{Sensitivity to ACCase-inhibiting and ALS- inhibiting herbicides}

The purified $\mathrm{R}$ population displayed high level resistance to APP herbicides, fenoxaprop- $P$-ethyl and clodinafoppropargyl (Table 3). The $\mathrm{GR}_{50}$ values were $757.3 \pm 30.2$ and $229.5 \pm 31.9 \mathrm{~g}$ ai ha ${ }^{-1}$ of fenoxaprop- $P$-ethyl and clodinafoppropargyl, respectively, which were much more than the field rates (Table 2) of the two herbicides. Some plants survived even at 27 -fold the field rates of fenoxaprop- $P$-ethyl and clodinafop-propargyl (data not shown). Compared with the $\mathrm{S}$ population, $R$ population was 86.1 - and 29.8 -fold resistant to fenoxaprop- $P$-ethyl and clodinafop-propargyl. In this study, the plants of the purified $\mathrm{R}$ population were sensitive to the CHD herbicides: sethoxydim and tralkoxydim. The RIs were less than 2 when compared with the S population (Table 3 ). It was particularly noteworthy that the purified $\mathrm{R}$ population had evolved low level (3.4-fold) resistance to pinoxaden (Table 3), though the $\mathrm{GR}_{50}$ value $\left(14.2 \pm 3.8 \mathrm{~g}\right.$ ai ha $\left.{ }^{-1}\right)$ was still less than its field rate $\left(45 \mathrm{~g}\right.$ ai ha $\left.{ }^{-1}\right)$.

The purified $\mathrm{R}$ population was highly resistant to mesosulfuron-methyl, moderately resistant to flucarbazonesodium and pyroxsulam, with the RI 32.6, 6.0, and 9.6, respectively (Table 3$)$. The $\mathrm{GR}_{50}$ value $\left(55.5 \pm 3.8 \mathrm{~g}\right.$ ai ha $\left.^{-1}\right)$ of mesosulfuron-methyl for the purified $\mathrm{R}$ population was six times as many as the field rate $\left(9 \mathrm{~g}\right.$ ai ha $\left.{ }^{-1}\right)$. About $46 \%$ and 53\% of plants survived pyroxsulam and flucarbazonesodium treatment at the recommended field rate, with nearly $70 \%$ and $63 \%$ growth reduction respectively (data not shown).

\section{Sensitivity to isoproturon and impact of PBO on dose-response to fenoxaprop- $P$ - ethyl}

The result showed that the purified $\mathrm{R}$ population is still very sensitive to the photosystem II inhibitor isoproturon (Table 3). 
Table 3. Parameters of the four-parameter log-logistic equation* used to calculate the $50 \%$ growth reduction (GR (G) $_{50}$ values of the purified resistant $(\mathbf{R})$ and susceptible $(\mathrm{S})$ populations of Alopecurus aequalis. Standard errors are in parentheses.

\begin{tabular}{|c|c|c|c|c|c|c|c|}
\hline \multirow[b]{2}{*}{ Herbicides } & \multirow[b]{2}{*}{ Populations } & \multicolumn{4}{|c|}{ Regression parameters } & \multirow[b]{2}{*}{$\mathrm{GR}_{50}(\mathrm{~g}$ ai ha-1) } & \multirow[b]{2}{*}{$\mathrm{R} 1$} \\
\hline & & $\mathrm{C}$ & $\mathrm{D}$ & $\mathrm{b}$ & $\mathrm{R}^{2}$ & & \\
\hline \multirow[t]{2}{*}{ Fenoxaprop- $P$-ethyl } & $\mathrm{R}$ & $8.5(11.0)$ & $91.4(4.4)$ & $-0.81(0.2)$ & 0.9974 & $757.3(30.2) \mathrm{a}$ & \multirow[b]{2}{*}{86.1} \\
\hline & $\mathrm{S}$ & $24.6(1.2)$ & $98.6(1.6)$ & $-1.41(0.1)$ & 0.9993 & $8.8(0.5) \mathrm{c}$ & \\
\hline \multirow[t]{2}{*}{ Fenoxaprop- $P$-ethyl + PBO (4200 g ai ha $\left.{ }^{-1}\right)$} & $\mathrm{R}$ & $12.9(5.8)$ & $77.6(3.0)$ & $-0.95(0.2)$ & 0.9974 & $588.9(24.5) \mathrm{b}$ & \multirow[b]{2}{*}{71.0} \\
\hline & $\mathrm{S}$ & $21.5(1.0)$ & $87.2(1.3)$ & $-1.73(0.1)$ & 0.9974 & $8.3(0.4) \mathrm{c}$ & \\
\hline \multirow[t]{2}{*}{ Clodinafop-propargyl } & $\mathrm{R}$ & $25.5(3.5)$ & $96.9(3.6)$ & $-0.96(0.2)$ & 0.9983 & $229.5(31.9)$ & \multirow{2}{*}{29.8} \\
\hline & $\mathrm{S}$ & $17.3(2.2)$ & $89.8(2.4)$ & $-1.83(0.3)$ & 0.9976 & $7.7(0.7)$ & \\
\hline \multirow{2}{*}{ Tralkoxydim } & $\mathrm{R}$ & $25.1(0.8)$ & $97.0(2.4)$ & $-0.95(0.1)$ & 0.9998 & $27.9(2.1)$ & \multirow{2}{*}{1.5} \\
\hline & $\mathrm{S}$ & $20.9(3.6)$ & $108.9(14.7)$ & $-0.72(0.2)$ & 0.9984 & $18.7(8.3)$ & \\
\hline \multirow[t]{2}{*}{ Sethoxydim } & $\mathrm{R}$ & $22.4(4.5)$ & $91.0(7.7)$ & $-0.65(0.1)$ & 0.9987 & $16.8(4.5)$ & \multirow[b]{2}{*}{1.9} \\
\hline & $\mathrm{S}$ & $15.5(4.5)$ & $97.3(16.4)$ & $-0.90(0.3)$ & 0.9948 & $8.7(4.1)$ & \\
\hline \multirow[t]{2}{*}{ Pinoxaden } & $\mathrm{R}$ & $8.9(13.6)$ & $98.4(10.0)$ & $-0.92(0.3)$ & 0.9941 & $14.2(3.8)$ & \multirow[b]{2}{*}{3.4} \\
\hline & $\mathrm{S}$ & $18.4(1.6)$ & $91.2(2.3)$ & $-1.57(0.2)$ & 0.9988 & $4.2(0.3)$ & \\
\hline \multirow[t]{2}{*}{ Mesosulfuron-methyl } & $\mathrm{R}$ & $18.5(9.1)$ & $93.6(8.1)$ & $-0.88(0.3)$ & 0.9933 & $55.5(3.8)$ & \multirow[b]{2}{*}{32.6} \\
\hline & $\mathrm{S}$ & $13.2(1.5)$ & $80.9(1.5)$ & $-1.44(0.1)$ & 0.9991 & $1.7(0.1)$ & \\
\hline \multirow[t]{2}{*}{ Pyroxsulam } & $\mathrm{R}$ & $9.2(28.2)$ & $94.8(24.7)$ & $-0.63(0.5)$ & 0.9845 & $2.3(1.8)$ & \multirow[b]{2}{*}{9.6} \\
\hline & $\mathrm{S}$ & $19.1(1.3)$ & $101.9(3.5)$ & $-1.57(0.2)$ & 0.9989 & $0.2(0.02)$ & \\
\hline \multirow[t]{2}{*}{ Flucarbazone-sodium } & $\mathrm{R}$ & $9.2(16.7)$ & $107.6(17.9)$ & $-0.50(0.2)$ & 0.9949 & $14.4(7.8)$ & \multirow[b]{2}{*}{6.0} \\
\hline & $\mathrm{S}$ & $18.6(1.3)$ & $97.9(1.9)$ & $-0.83(0.1)$ & 0.9997 & $2.4(0.2)$ & \\
\hline \multirow[t]{2}{*}{ Isoproturon } & $\mathrm{R}$ & $19.6(3.4)$ & $99.3(6.3)$ & $-4.23(1.4)$ & 0.9908 & $90.2(9.5)$ & \multirow[b]{2}{*}{0.6} \\
\hline & $\mathrm{S}$ & $22.7(6.6)$ & $100.7(7.8)$ & $-1.55(0.5)$ & 0.9940 & $143.2(23.6)$ & \\
\hline
\end{tabular}

$* y=\mathrm{C}+(\mathrm{D}-\mathrm{C}) /\left\{1+\exp \left[\mathrm{b}\left(\operatorname{logx}-\log \mathrm{GR}_{50}\right)\right]\right\}$, where $y$ is the percentage of the control, $C$ and $D$ are lower and upper asymptotic limits, $b$ is the slope of the curve through $\mathrm{GR}_{50}$.

Means with different letters are significantly different according to Tukey's HSD test $(\alpha=0.05)$. Resistance index $(\mathrm{RI})$ was calculated as the ratio of GR 50 values of the $\mathrm{R}$ and $\mathrm{S}$ populations.

PBO: Piperonyl butoxide.

At the lower limit of the isoproturon field rate $\left(900 \mathrm{~g}\right.$ ai ha$\left.^{-1}\right)$, all plants from the $\mathrm{R}$ and $\mathrm{S}$ populations were totally dead.

When PBO was applied alone at $4200 \mathrm{~g}$ ai $\mathrm{ha}^{-1}$, there was no apparent effect on survival or biomass of either the $\mathrm{S}$ or $\mathrm{R}$ population (data not shown). With PBO pretreatment (4200 g ai ha $\left.{ }^{-1}\right)$, the $\mathrm{GR}_{50}$ value of fenoxaprop- $P$-ethyl decreased $22 \%$ for the purified $\mathrm{R}$ population, from $757.3 \pm 30.2$ to $588.9 \pm 24.5 \mathrm{~g}$ ai ha ${ }^{-1}$ (Table 3, Figure 2). In comparison, it decreased less than $6 \%$ for the $\mathrm{S}$ population, from $8.8 \pm 0.5$ to $8.3 \pm 0.4 \mathrm{~g}_{\text {ai ha }}{ }^{-1}$ (Table 3, Figure 2).

Figure 2. Dose-response curves for dry weight of the resistant (R) and susceptible (S) Alopecurus aequalis populations treated with a range of fenoxaprop- $P$-ethyl doses plus or minus $4200 \mathrm{~g}$ ai ha ${ }^{-1}$ piperonyl butoxide (PBO). The values are expressed as the percentage of the untreated control.

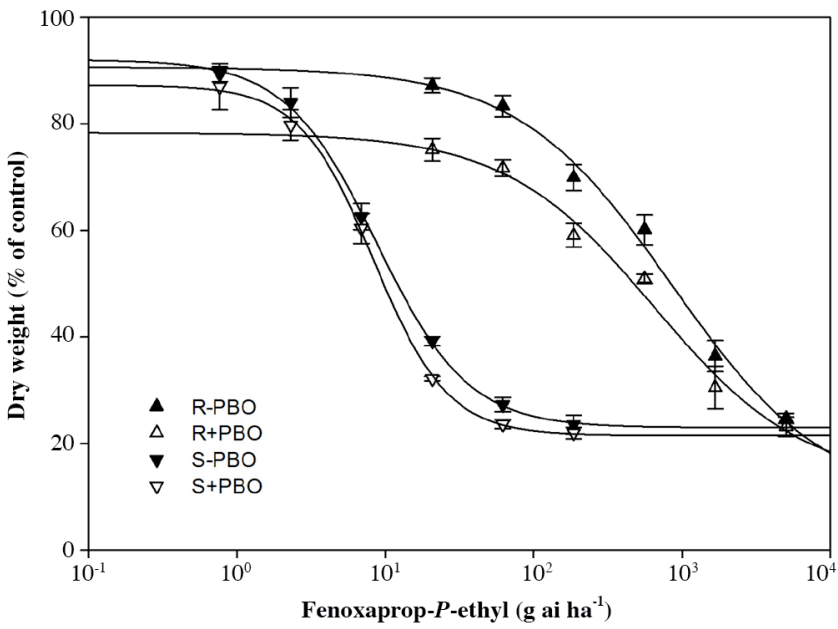

\section{DISCUSSION}

In recent years, multiple resistance to ACCase and ALSinhibiting herbicides in some grass weeds has become a serious threat for wheat production in China (Bi et al., 2016). Both ACCase and ALS are prone to resistance evolution as the action site of herbicide (Beckie and Tardif, 2012; Yu and Powles, 2014a). In this study, the R population collected from Shou County has evolved high level resistance to fenoxaprop- $P$-ethyl and mesosulfuron-methyl (Table 3) after repeated use for several years. In individual plant of the $\mathrm{R}$ population, $\mathrm{Ile}_{2041}$ Asn mutation and $\mathrm{PrO}_{197} \mathrm{Arg}$ mutation were detected simultaneously. According to the owner of the field, fenoxaprop- $P$-ethyl was applied $7 \sim 8$ yr earlier than that of mesosulfuron-methyl in this area.In addition, the controleffect of fenoxaprop- $P$-ethyl had decreased before mesosulfuronmethyl's commercialization in this area. Therefore, there was a possibility that the ACCase $\mathrm{Ile}_{2041}$ Asn mutation first appeared in the R population and it was inherited though the ALS-inhibiting herbicide mesosulfuron-methyl was used and resistance evolution ( Pro $_{197}$ Arg mutation). This deduction was in accordance with the result that all individual plant $(\mathrm{n}=$ 48) possessed the homozygous ACCase Ile 2041 Asn mutation and only one-third of the plants (16 out of 48) possessed the homozygous ALS Pro ${ }_{197} A r g$ mutation. Similar result has been reported in L. rigidum that the ACCase resistance traits were preserved in spite of the interruption of ACCase applications for $7 \mathrm{yr}$ (Collavo et al., 2013). Considering the fact that $A$. aequalis is diploid and partly cross-pollinated (Morishma and Oka, 1980), it is very likely that most of the plants in the $\mathrm{R}$ population will have a homozygous ALS mutation, together 
with the homozygous ACCase mutation, in the near future. Therefore, because of the risk of multiple resistance, it is not an ideal choice to manage ACCase-resistant A. aequalis by single use of ALS herbicide.

The Ile $_{2041}$ Asn mutation is a well-known mutation endowing ACCase herbicide resistance and has been documented in many weed species (reviewed in Powles and Yu, 2010). Generally, this mutation is highly resistant to APPs, sensitive or moderately resistant to CHDs and DEN in A. myosuroides (Délye et al., 2003), L. rigidum (Zhang and Powles, 2006), Phalaris paradoxa (Hochberg et al., 2009), and Avena fatua (Cruz-Hipolito et al., 2011). In the present study, the $\mathrm{Ile}_{2041} \mathrm{Asn}$ mutant ACCase, reported for the first time in A. aequalis, was involved in high level resistance to APPs, low level resistance to pinoxaden, but no resistance to CHDs. Tralkoxydim is a CHD herbicide and can selectively control grass weeds in wheat field. Based on our results, tralkoxydim can still be used to control the $\mathrm{R}$ population of A. aequalis with $\mathrm{Ile}_{2041}$ Asn mutation (Table 3 ). However, from the sustainable management point of view, an herbicide rotation with herbicides having the same mode of action is not recommended, let alone the ACCase mutations endowing CHDs resistance have been reported in A. aequalis (Guo et al., 2015). Pinoxaden was the latest ACCase herbicide introduced into China in 2010. The $\mathrm{R}$ population in this study was slight resistant to pinoxaden (Table 3 ) though it had never been applied. This was in accordance with former researches that the weeds evolved pinoxaden resistance before its commercialization (Petit et al., 2010).

This study reports for the first time the Pro ${ }_{197} \mathrm{Arg}$ substitution in A.aequalis. Among 12 amino acid substitutions identified at $\mathrm{PrO}_{197}$ of ALS gene, the frequency of Pro ${ }_{197} \mathrm{Arg}$ is relatively low compared with other Pro 197 substitutions. Pro ${ }_{197}$ Arg has been reported in only four weed species and confers high level resistance to SU but low level resistance to TP and PTB herbicides (Beckie and Tardif, 2012). However, using the purified population homozygous for Pro ${ }_{197} \mathrm{Arg}$, we found this mutation conferring moderate resistance to SCT (flucarbazone-sodium) and TP (pyroxsulam) herbicides in A. aequalis. This demonstrates that cross-resistance pattern is dependent not only on the specific mutation (mutation site and amino acid) but also on specific herbicides and weed species (Yu and Powles, 2014a). It also indicated us that these two herbicides were no longer applicable for controlling the $\mathrm{R}$ population of $A$. aequalis in wheat field.

In this study, isoproturon still had an ideal control effect on both populations of $A$. aequalis. Therefore, isoproturon may perform a useful role in managing ACCase and/or ALS resistant weeds though it has been commercialized for many years in China. Nonetheless, people had better apply isoproturon in combination with other herbicides (such as isoproturon + diflufenican) to prevent or delay resistance evolution. Our unpublished results revealed that the herbicide mixture flufenacet, flurtamonec, diflufenican (Bacara Forte 360 SC, Bayer CropScience, Monheim am Rhein, Germany) could effectively control some ACCase and ALS resistant weeds in the fields.
Previous studies have proved that PBO, as a cytochrome P450 inhibitor, could synergize some herbicides in several weed species, including: chlorotuluron and simazine in $L$. rigidum (Preston et al., 1996), ethametsulfuron-methyl in Sinapis arvensis L. (Veldhuis et al., 2000), bispytibac-sodium in Echinochloa phyllopogon (Stapf) Stapf ex Kossenko (Fisher et al., 2000), fenoxaprop-P-ethyl in Poa annua L. (Wang et al., 2013). In the current study, pretreatment with $\mathrm{PBO}$ decreased the $\mathrm{GR}_{50}$ value of fenoxaprop- $P$-ethyl by $22 \%$ in the purified $\mathrm{R}$ population while only $6 \%$ in the $\mathrm{S}$ population, suggesting that an enhanced metabolism mediated by cytochrome P450 monooxygenase may also play a role in fenoxaprop- $P$-ethyl resistance of the $\mathrm{R}$ population. Non-target-site resistance is now increasingly identified as the major resistance mechanism to ACCase herbicides (Délye et al., 2011). Additionally, NTSR often exists in populations containing target-site based resistance (Ahmad-Hamdani et al., 2012; Kaundun et al., 2013). Given the complexity of NTSR, further researches need to be done to investigate the NTSR in A. aequalis.

\section{CONCLUSIONS}

In conclusion, the $\mathrm{R}$ population of Alopecurus aequalis evolved high-level resistance to fenoxaprop- $P$-ethyl and mesosulfuron-methyl, and showed different cross resistance levels to other herbicides. Target-site mutations ( $\mathrm{Ile}_{2041} \mathrm{Asn}$ in acetyl-CoA carboxylase and Pro $_{197}$ Arg in acetolactate synthase) and cytochrome P450 monooxygenase may both play a role in resistance to herbicides of $A$. aequalis.

\section{ACKNOWLEDGEMENTS}

This research was funded by the National Natural Science Foundation of China (31471787) and the Special Fund for Agroscientific Research in the Public Interest (201303031).

\section{REFERENCES}

Ahmad-Hamdani, M.S., Q. Yu, H. Han, G.R. Cawthray, S.F. Wang, and S.B. Powles. 2012. Herbicide resistance endowed by enhanced rates of herbicide metabolism in wild oat (Avena spp.). Weed Science 61:55-62.

Beckie, H.J. 2006. Herbicide-resistant weeds: management tactics and practices. Weed Technology 20:793-814.

Beckie, H.J., and F.J. Tardif. 2012. Herbicide cross resistance in weeds. Crop Protection 35:15-28.

Bi, Y.L., W.T. Liu, W.L. Guo, L.X. Li, G.H. Yuan, L. Du, et al. 2016. Molecular basis of multiple resistance to ACCase- and ALS-inhibiting herbicides in Alopecurus japonicus from China. Pesticide Biochemistry and Physiology 126:22-27. doi:10.1016/j. pestbp.2015.07.002.

Collavo, A., H. Strek, R. Beffa, and M. Sattin. 2013. Management of an ACCase-inhibitor-resistant Lolium rigidum population based on the use of ALS inhibitors: weed population evolution observed over a 7 year field-scale investigation. Pest Management Science 69:200-208. 
Cruz-Hipolito, H., M.D. Osuna, J.A. Dominguez-Valenzuela, N. Espinoza, and R. de Prado. 2011. Mechanism of resistance to ACCase-inhibiting herbicides in wild oat (Avena fatua) from Latin America. Journal of Agricultural and Food Chemistry 59:7261-7267.

Délye, C., J.A.C. Gardin, K. Boucansaud, B. Chauvel, and C. Petit. 2011. Non-target-site-based resistance should be the centre of attention for herbicide resistance research: Alopecurus myosuroides as an illustration. Weed Research 51:433-437.

Délye, C., S. Michel, A. Bérard, B. Chauvel, D. Brunel, J.P. Guillemin, et al. 2010. Geographical variation in resistance to acetyl-coenzyme A carboxylase-inhibiting herbicides across the range of the arable weed Alopecurus myosuroides (black-grass). New Phytologist 186:1005-1017.

Délye, C., X.Q. Zhang, C. Chalopin, S. Michel, and S.B. Powles. 2003. An isoleucine residue within the carboxyl-transferase domain of multidomain acetyl-coenzyme A carboxylase is a major determinant of sensitivity to aryloxyphenoxypropionate but not to cyclohexanedione inhibitors. Plant Physiology 132:1716-1723.

Duggleby, R.G., J.A. McCourt, and L.W. Guddat. 2008. Structure and mechanism of inhibition of plant acetohydroxyacid synthase. Plant Physiology and Biochemistry 46:309-324.

Fisher, A.J., D.E. Bayer, M.D. Carriere, C.M. Ateh, and K.O. Yim. 2000. Mechanisms of resistance to bispyribac-sodium in an Echinochloa phyllopogon accession. Pesticide Biochemistry and Physiology 28:156-165.

Guo, W., W. Liu, L. Li, G. Yuan, L. Du, and J. Wang. 2015. Molecular basis for resistance to fenoxaprop in shortawn foxtail (Alopecurus aequalis) from China. Weed Science 63:416-424.

Han, H., Q. Yu, M.J. Owen, G.R. Cawthray, and S.B. Powles. 2016. Widespread occurrence of both metabolic and target-site herbicide resistance mechanisms in Lolium rigidum populations. Pest Management Science 72:255-263. doi:10.1002/ps.3995.

Heap, I.M. 2015. International survey of herbicide resistant weeds. Available at http://www.weedscience.org (accessed October 2015).

Herbert, D., K.A. Walker, L.J. Price, D.J. Cole, K.E. Pallett, S.M. Ridley, et al. 1997. Acetyl-CoA carboxylase: a graminicide target site. Pesticide Science 50:67-71.

Hochberg, O., M. Sibony, and B. Rubin. 2009. The response of ACCase-resistant Phalaris paradoxa populations involves two different target site mutations. Weed Research 49:37-46.

Hofer, U., M. Muehlebach, S. Hole, and A. Zoschke. 2006. Pinoxaden-for broad spectrum grass weed management in cereal crops. Journal of Plant Diseases and Protection 113:989-995.

Incledon, B.J., and C.J.Hall. 1997. Acetyl-coenzyme A carboxylase: quaternary structure and inhibition by graminicidal herbicides. Pesticide Biochemistry and Physiology 57:255-271.

Kaundun, S.S. 2014. Resistance to acetyl-CoA carboxylaseinhibiting herbicides. Pest Management Science 70:1405-1417.

Kaundun, S.S., G.C. Bailly, R.P. Dale, S.J. Hutchings, and E. Mclndoe. 2013. A novel W1999S mutation and non-target site resistance impact on Acetyl-CoA carboxylase inhibiting herbicides to varying degrees in a UK Lolium multiflorum population. PLoS ONE 8:e58012.

Konishi, T., and Y. Sasaki. 1994. Compartmentalization of two forms of acetyl-CoA carboxylase in plants and the origin of their tolerance toward herbicides. Proceedings of the National Academy of Sciences of the United States of America 91:3598-3601.

Konishi, T., K. Shinohara, K. Yamada, and Y. Sasaki. 1996. Acetyl-CoA carboxylase in higher plants: most plants other than Gramineae have both the prokaryotic and the eukaryotic forms of this enzyme. Plant and Cell Physiology 37:117-122.
Morishma, H., and H.I. Oka. 1980. The impact of copper pollution on water foxtail (Alopecurus aequalis Sobol.) populations and winter weed communities in rice fields. Agro-Ecosystem 6:33-49.

Owen, M.J., D. Goggin, and S.B. Powles. 2012. Non-target-sitebased resistance to ALS-inhibiting herbicides in six Bromus rigidus populations from Western Australian cropping fields. Pest Management Science 68:1077-1082.

Petit, C., G. Bay, F. Pernin, and C. Délye. 2010. Prevalence of crossor multiple resistance to the acetyl-coenzyme A carboxylase inhibitors fenoxaprop, clodinafop and pinoxaden in black-grass (Alopecurus myosuroides Huds.) in France. Pest Management Science 66:168-177.

Powles, S.B., and Q. Yu. 2010. Evolution in action: plants resistant to herbicides. Annual Review of Plant Biology 61:317-347.

Preston, C., F.J. Tardif, J.T. Christopher, and S.B. Powles. 1996. Multiple resistance to dissimilar herbicide chemistries in a biotype of Lolium rigidum due to enhanced activity of several herbicide degrading enzymes. Pesticide Biochemistry and Physiology 54:123-134.

Sasaki, Y., and Y. Nagano. 2004. Plant acetyl-CoA carboxylase: structure, biosynthesis, regulation, and gene manipulation for plant breeding. Bioscience Biotechnology and Biochemistry 68:1175-1184.

Seefeldt, S.S., J.E. Jensen, and E.P. Fuerst. 1995. Log-logistic analysis of herbicide dose-response relationships. Weed Technology 9:218-227.

Tranel, P.J., T.R. Wright, and I.M. Heap. 2015. Mutations in herbicide-resistant weeds to ALS inhibitors. Available at http:// www.weedscience.com (accessed October 2015).

Veldhuis, L.J., L.M. Hall, J.T. O’Donovan, W. Dyer, and J.C. Hall. 2000. Metabolism-based resistance of a wild mustard (Sinapis arvensis L.) biotype to ethametsulfuron-methyl. Journal of Agricultural and Food Chemistry 48:2986-2990.

Wang, H., J. Li, B. Lv, Y. Lou, and L. Dong. 2013. The role of cytochrome $\mathrm{P} 450$ monooxygenase in the different responses to fenoxaprop-P-ethyl in annual bluegrass (Poа апnиa L.) and short awned foxtail (Alopecurus aequalis Sobol.) Pesticide Biochemistry and Physiology 107:334-342.

Yu, Q., and S.B. Powles. 2014a. Resistance to AHAS inhibitor herbicides: current understanding. Pest Management Science 70:1340-1350.

Yu, Q., and S.B. Powles. 2014b. Metabolism-based herbicide resistance and cross-resistance in crop weeds: a threat to herbicide sustainability and global crop production. Plant Physiology 166:1106-1118.

Zhang, Z.P. 2003. Development of chemical weed control and integrated weed management in China. Weed Biology Management 3:197-203.

Zhang, X.Q., and S.B. Powles. 2006. Six amino acid substitutions in the carboxyl-transferase domain of the plastidic acetyl-CoA carboxylase gene are linked with resistance to herbicides in a Lolium rigidum population. New Phytologist 172:636-645.

Zhang, H., Z. Yang, Y. Shen, and L. Tong. 2003 Crystal structure of the carboxyltransferase domain of acetyl-coenzyme A carboxylase. Science 299:2064-2067.

Zhu, W.D., and S.X. Tu. 1997. Study on damage from Alopecurus aequalis Sobol. and its economical threshold in wheat fields of Hubei province. Journal of Huazhong Agricultural University 3:268-271 [In Chinese]. 